\title{
REPORT ON BOTANICAL EXPLORATIONS IN ARCTIC AMERICA, 1946-48
}

By Nicholas Polunin*

\begin{abstract}
$\mathbf{I}^{\mathrm{r}}$ Is possible only in rather general terms to comply with the request from the Arctic Institute of North America for an account of my post-war botanical and related field-work in northern Canada and Alaska, as most of the material and observations have yet to be worked up. Moreover a book describing the first summer is in the press $^{1}$ and it is hoped to find time to write some account of further experiences at a later date.
\end{abstract}

\section{Eastern Arctic in 1946}

On the invitations of McGill University to a Visiting Professorship and of the Arctic Institute to a Research Fellowship, I came from England in the summer of 1946 and, through the courtesy of the Northwest Territories Administration and the Geodetic Service of Canada (both of which organizations come within the federal Department of Mines and Resources), was without delay taken by Royal Canadian Air Force 'planes via Bagotville to a first base-camp in lat. $55^{\circ} 15^{\prime} \mathrm{N}$. and long. $7^{\circ} 21^{\prime} \mathrm{W}$. on Lac Bienville in central Ungava. The country hereabouts forms part of a plateau some $145^{\circ}$ feet in altitude and has a rather gently undulating surface of smooth sandy hills averaging perhaps 100 feet in height. The depressions were often occupied by lakes which, with innumerable smaller tarns, appeared from the air to account for as much as half the area in some places. In the vicinity of the base-camp the main vegetation types away from water were only three, viz. (I) treeless areas occupying perhaps a quarter of the total land, and usually raised and exposed, of light-coloured 'Caribou-moss' (largely a mixture of lichens of the genus Cladonia) between the low bushy clumps of the dominant Scrub Birch (Betula glandulosa); (2) sparsely-wooded areas occupying most of the remaining land and characterized by poor scrub and similar but more luxuriant Caribou-moss; and (3) relatively lush, often marshy forest with thick scrub up to a yard high that contained plentiful herbs, and with true mosses replacing lichens on the ground.

Black Spruce (Picea mariana) was the dominant tree almost everywhere, growing in dense clumps owing to 'layering' but nevertheless in rather sparsely open formation as a whole, rarely occupying more than a quarter of the area of the scrubby 'forest'. Although an occasional individual exceeded 30 feet in height and 8 inches in diameter of the trunk near the base, growth was usually poor, the trees being more often about 15 feet high, having a trunk diameter of only 3 to 4 inches, and showing some 60 to 100 annual rings. The only other trees encountered around Lac Bienville were Tamarack (Larix laricina), which were usually to be found scattered amongst the Spruces and were sometimes of better growth-especially in low-lying, damp tracts. Around lake margins tall bushes of Green Alder (Alnus crispa) formed a dense scrub which often exceeded 6 feet in height and harboured ranker herbs than most other habitats.

*Macdonald Professor of Botany, McGill University, Montreal. 


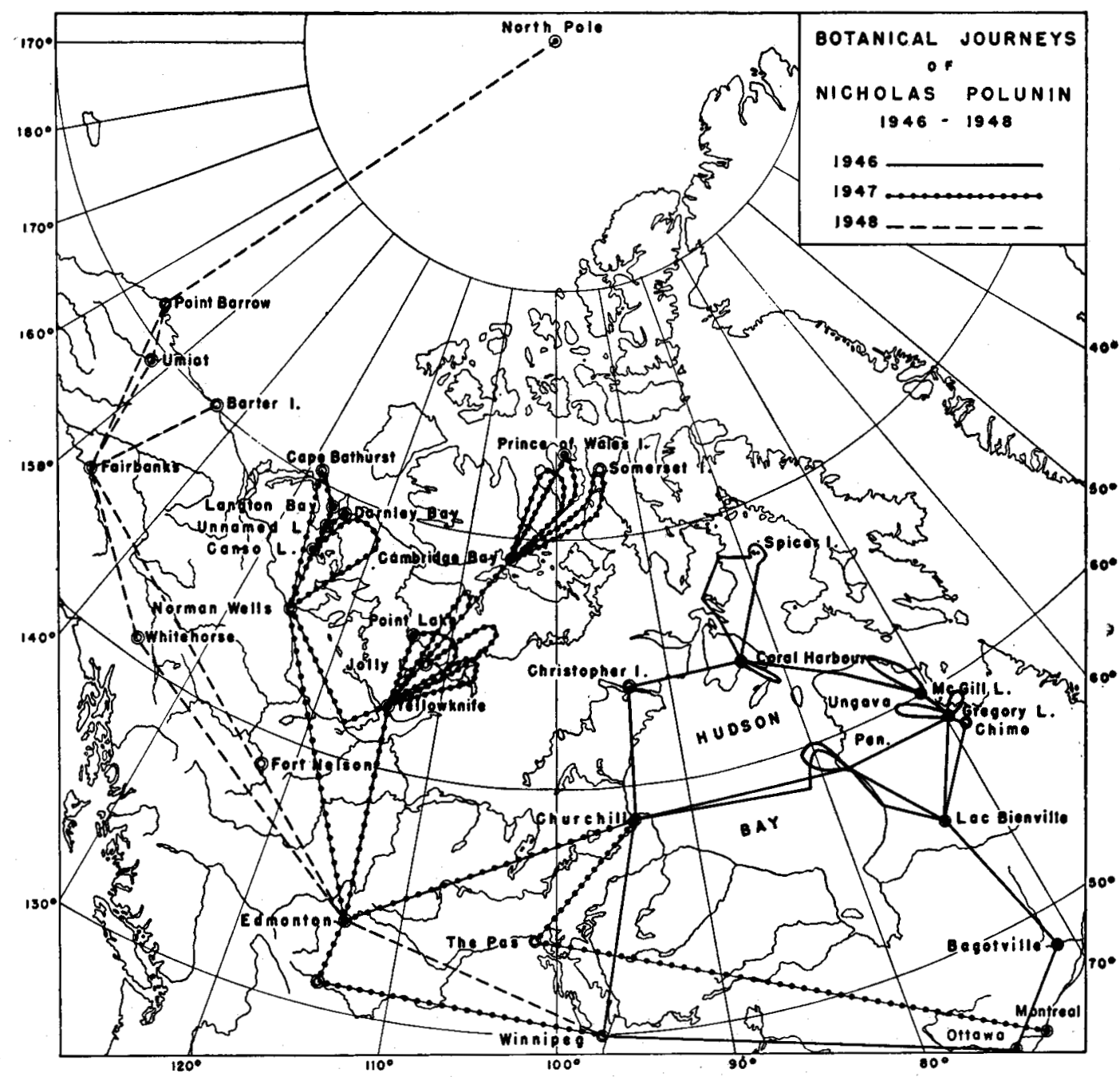

Flight lines are only approximate. No landings made at Somerset Island or North Pole.

In accordance with the limited number of different plant habitats and communities, the total flora was rather small; moreover the soils were acid and apparently poor in nitrogenous and other plant foods, so that growth and development tended to be limited especially in the case of herbs. Indeed lichens often predominated on the ground, where, owing to the porous nature of the sandy or sometimes gravelly substratum, the surface tended to become arid. This appeared to be another reason for the limitation of the flora and for the fact that over most areas lichens formed a dense sward from 2 to 5 inches thick that was almost uninterrupted by 'higher' plants.

With my transference in mid-July to Chimo it was possible to make detailed observations on the vegetation and collections of the flora in the vicinity of the airfield in lat. $58^{\circ} \mathrm{oz}^{\prime} \mathrm{N}$. and long. $68^{\circ} 3 \mathrm{o}^{\prime} \mathrm{W}$. In spite of the more northerly location, the forest here tended to be more luxuriant than around Lac Bienville-especially near sea level on the banks of the Koksoak 
River, although at Chimo it was much interrupted by marshes and rocky hills as well as by lakes, and to the southwest as well as to the north it thinned out markedly. In keeping with this wide range of habitats, the total flora at Chimo was large and the vegetation variable, the plant communities tending to be complex and intricately mixed. Consequently an unusual number of days had to be spent collecting the flora and contemplating the ecological relationships before a survey of the vegetation could be commenced in earnest. The main vegetation types or other categories which were distinguished and investigated, and which between them covered practically the whole of the land area, were (I) dry coniferous forest (usually dominated by mixed Black Spruce and Tamarack) with subdominant ground-shrubs and lichen sward in alternating patches, (2) relatively lush boggy forest with Willows subdominant and a mixed ground-flora, (3) dry Birch scrub, (4) damp Willow scrub, (5) dry lichen-rich and damper, more mossy, heaths, (6) exposed rocky hill-tops, etc., (7) marshes and acid-bogs, (8) lake-marginal zones. In addition some interesting aquatic, late-snow, burned or otherwise disturbed, deciduous tree (Balsam Poplar Populus balsamifera), estuary-shore, stream-side, spring-flush, rock-face and other areas and communities were investigated and listed as regards plant components.

During flights from Chimo westwards over Ungava Peninsula it was confirmed that the forest thinned out and almost disappeared before resuming about the banks of Leaf River. Thereafter, to the north and west, no trees were seen and the vegetation looked in general rather dwarf and poor, consisting for the most part of lichen-rich heaths interrupted by rocky outcrops, boulder-fields, or gravelly hills-with marshes clothing damper depressions and innumerable lakes and tarns almost everywhere.

With the establishment of another base-camp before the end of July in lat. $58^{\circ} 27^{\prime} \mathrm{N}$. and long. $70^{\circ} \mathrm{o} 8^{\prime} \mathrm{W}$. on Gregory Lake, it was possible to spend much of the ensuing four weeks making extensive plant collections thereabouts, and detailed ecological and other investigations. The country was flat or gently undulating around 220 feet above sea level-except where it rose to steeper slopes that extended to a broken plateau about $7^{00}$ feet in altitude. These uplands, although exposed and relatively barren, with the surface widely disturbed by soil 'polygons', were nevertheless often grassy, with an abundance of Sedges and Willows in marshy depressions, and a wide array of herbs in sheltered ravines and about late-snow patches. The lowland plains were largely vegetated by lichen-rich heaths in dry areas and sedgy marshes in wet ones. Cotton-grasses (Eriophorum spp.) were often codominant in the marshes with Sedges etc., and mosses (including Bog-mosses, Sphagnum spp.) usually subdominant; such areas were often tussocky, of the 'hillock-tundra' type. Lake and stream margins in many places supported tall and thick Willow scrub, and sunny banks much Scrub Birch. Although it was more limited than at Chimo, the associated herbaceous flora was extensive and its growth fairly luxuriant. In exposed spots in the uplands there were to be found many northern types, especially where 'open soil' and other conditions reminiscent of the far North obtained; in suitably sheltered situations in the lowlands there 
were southern types persisting here to the north (at all events climatically) of their previously known limit.

Such intermittent tracts of 'forest' as remained around Gregory Lake were scarcely deserving of the name. They consisted of straggly Tamaracks that were often individually of fair growth but stood in sparsely open formation. The Black Spruces rarely attained tree dimensions, being for the most part depauperated espaliers that in winter remained beneath the protective snow-blanket. The timbered tracts were chiefly developed in sheltered 'angles' formed by the lower slopes of the hills and the ongoing plains at their feet, and appeared to have been considerably disturbed by natives; their groundvegetation was largely of heathy shrubs and lichens that formed a fair Caribou-moss sward but were also abundant on the surrounding treeless plains.

The different habitats and plant communities around Gregory Lake were numerous and variable, most southern types persisting even if in depauperated form but many northern ones entering especially in the uplands-as in the case of the flora. At least one example of each distinguishable type was investigated as regards soil and other conditions and listed as regards floristic composition, the main ones, occupying most of the area, being much as at Chimo -except for the less extensive forest and the tendency to less luxuriant growth at Gregory Lake.

On exploratory flights westwards over Hudson Bay and northwards as far as and along Hudson Strait, it became clear that much of northernmost Ungava was unexpectedly barren both inland and on islands, though on the mainland near the coast Willow and Birch scrub persisted on favourable, sheltered slopes and the banks of streams. Around lat. $60^{\circ}$ I $6^{\prime} \mathrm{N}$. and long. $7^{\circ} \mathrm{oo}^{\prime} \mathrm{W}$., where a landing was made and some days were spent investigating the southern shore and hinterland of McGill Lake, the country was undulating and on the whole surprisingly barren. The terrain was of usually rounded hills rising at most a few hundred feet from a general altitude of about 900 feet, with extensive boulder fields and 'heaths' dominated by lichens, the flora being surprisingly limited and the vegetation almost everywhere depauperate, with no proper scrub.

Early in the second half of August I transferred to Coral Harbour, Southampton Island, with headquarters on the airfield in lat. $64^{\circ} 10^{\prime} \mathrm{N}$. and long. $83^{\circ} 20^{\prime} \mathrm{W}$. The flora and vegetation of this district are treated in Parts I-III of "Botany of the Canadian Eastern Arctic", but many useful additional observations were made during the ensuing week of collecting and vegetation survey that was continued on a subsequent visit. Thus during an exploratory walk northward into the interior, it was observed that the vegetation tended to become less meagre than near the coast, there being plentiful scrubby Willows and even some low, heath-like Scrub Birch ${ }^{2}$. Even where they were of limestone, large areas of the flat or gently rolling plains near. sea-level but well inland were occupied by marshes dominated by Sedges and Cotton-grasses and bordered by Willows, and on the granitic or sandy areas there were often extensive lichen-rich or somewhat grassy heaths. About sheltered stream-banks the vegetation was apt to be quite luxuriant and productive of bird, mammalian, 
and insect life-especially where the rocks were dark and acid-weatheringso that many additions were made to the known flora of the island ${ }^{3}$.

A final base-camp having been established on Christopher Island near the eastern end of Baker Lake, Keewatin, I transferred to it on August 23 and remained there (apart from one brief interlude) until the expedition was forced south by oncoming winter early in September. The interlude was for a return to Southampton Island and a reconnaissance flight thence over Foxe Basin and Melville Peninsula. The interior of this last appeared to be surprisingly barren but some of the coastal regions especially in the south bore tracts that supported what looked like continuous vegetation, as did parts of the Spicer Archipelago and other low limestone islands of Foxe Basin. On this flight were sighted several new islands, including some of considerable size both to the north and to the east of the Spicers ${ }^{1}$.

The eastern part of Keewatin north of Chesterfield Inlet looked dark and rocky though interrupted by innumerable lakes and tarns. It appeared little if at all better vegetated than the acid-weathering parts of Southampton Island, though yellowish lichens were more noticeable on it-as in many other regions away from the coast. Well inland towards Baker Lake, however, the vegetation was more luxuriant, with extensive marshes and scrub in the valleys and more dark-brown to yellowish, lichen-rich communities showing about the gray and scoured 'hog's back' hills.

Christopher Island was rather hilly and on it were Caribou, Wolves, and plentiful smaller mammals as well as many birds. Although anything approaching tree growth was absent, the flora was considerable and the vegetation continuous in favourable areas. Extensive collections were made, as well as a detailed survey of the vegetation under the following main headings: ( 1 ) damp mossy heath, (2) dry lichen-rich heath, (3) mixed Willow-Birch scrub, (4) sandy etc. lakeside slopes, (5) marshes and lakeside flats, (6) hill-top rocks and boulders, (7) tarns and their marginal communities. Although there were fresh-looking shell-bank and other indications that the smooth lowland plains had risen out of the sea only in relatively recent times, the soil development was fair. However, little humus accumulation was observed and the soil-water reaction was usually near neutrality. For a hundred miles or so to the south the vegetation appeared to change little in general aspect, but near Churchill the forest was far more luxuriant than any seen on the ground since leaving Bagotville.

At Churchill I was able to supplement my work of 1934 and 1936 with further collections and ecological observations before returning via Winnipeg to Ottawa, and so ending a successful though economical period through which, with the splendid collaboration of the R.C.A.F. and Geodetic Service personnel, the National Museum of Canada will benefit by the choice from some 5,00o collection numbers of vascular plants and a considerable amount of cryptogamic material. This last is being determined by appropriate specialists in the United States and Europe.

\section{Northwestern Canada in 1947}

The summer of 1947 was spent in northwestern Canada, facilities being again afforded through the courtesy of the Department of Mines and Resources 
and the R.C.A.F. Leaving Montreal before the end of June, I flew west via The Pas and Churchill to Edmonton and thence northwards to Norman Wells, where it was necessary to hold until July i4 before the ice was sufficiently clear on the lakes to the north to allow the establishment of a base-camp nearer the coast. Meanwhile extensive collections of the vascular plants were made around Norman Wells and on the mountains to the east, the flora being large in conformity with the physiographically, climatically, edaphically and otherwise variable habitats. Thus in the sheltered Mackenzie Valley the forests were often luxuriant and mixed, with Poplars and Birches attaining tree dimensions and the dominant conifers tall where undisturbed; the undergrowth was in many places so dense as to be difficult to penetrate, and the herbs and ground-shrubs were luxuriant in the extreme. But on the Norman (Discovery) Range forming the eastern bank of the valley the vegetation soon thinned out, especially on the limestone, as far more rigorous conditions prevailed. Time did not allow a survey to be made of the vegetation, which was too variable and the plant communities too intricate to tackle in the few days available for such a purpose.

Following several reconnaissance flights the northern base-camp was established in lat. $67^{\circ} 37^{\prime} \mathrm{N}$. and long. $127^{\circ} 08^{\prime} \mathrm{W}$. beside a large and apparently unnamed sheet of water which we called Canso Lake. This was about 108 miles northwest of the most northwesterly extremity of Great Bear Lake and well within the forested zone, the country for many miles around being of much the same rolling type, beset with lakes and tarns of all sizes, and rather reminiscent of the interior of the Ungava Peninsula some ten degrees of latitude farther south. From the air even the forest looked similar, consisting of more or less sparsely-scattered dark conifers set in a background of light-coloured and evidently lichen-rich ground vegetation; but in dominance and some other details it differed at least from that around Lac Bienville (see above). Apart from lakes, the chief interruption of the forest appeared to be by burning, though this had rarely been in recent years. During flights to the north, observations were made on the northern limit of tree growth in many places; although in general this appeared to be as indicated on the latest Canadian National Topographic Series of 8-inch maps, considerable emendation will be necessary in some places.

In the vicinity of the base-camp some days were spent collecting the flora and then surveying the vegetation. The former proved to be very much more limited than at Norman Wells, and the latter less variable and luxuriant. Few southern species persisted, although on the most favourable south- or west-facing sandy or gravelly slopes there were to be found a dwarf Rose and plentiful Buffalo-berry (Shepherdia canadensis), in heathy habitats Russian Broomrape (Boschniakia rossica), and in shallow water Variegated Pond-lily (Nuphar variegatum), Swamp Horsetail (Equisetum limosum), and Ivy-leaved Duckweed (Lemna trisulca). Beaver were the only sizeable mammals seen, but tracks of Bears were plentiful and there were signs of Moose and Caribou.

Apart from a very few seedlings or small saplings of Balsam Poplar, no broad-leaved deciduous tree species was encountered, White Spruce (Picea glauca) being almost everywhere dominant. Both Tamarack and Black Spruce 


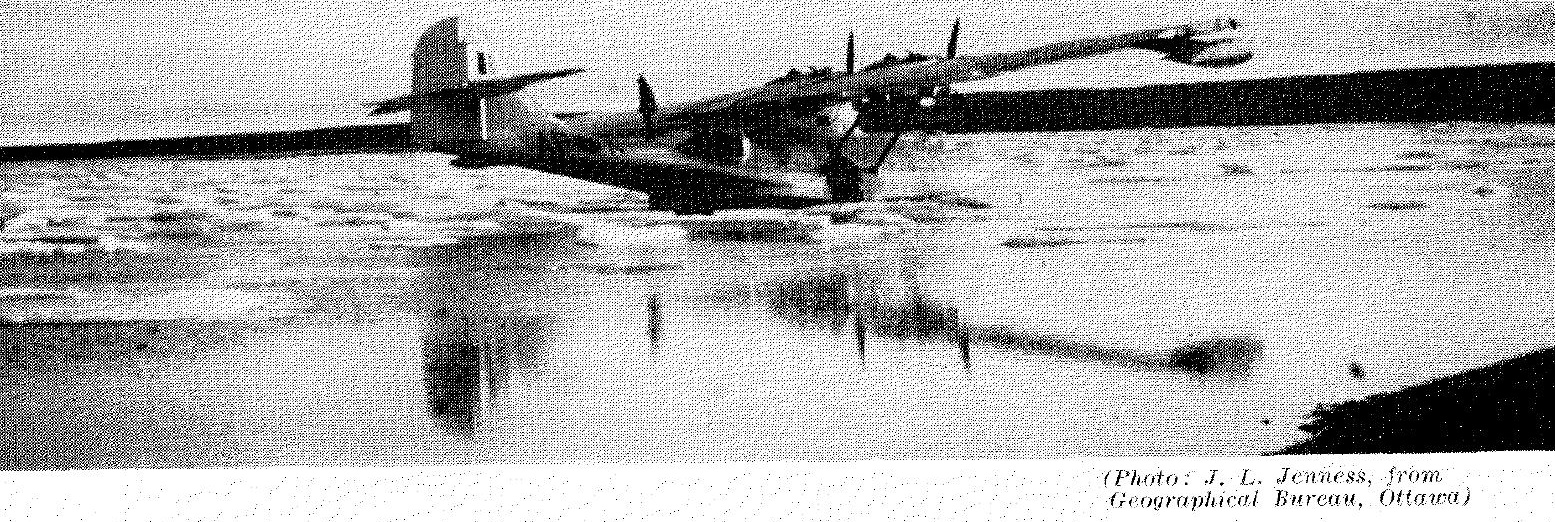

R.C.A.F. Canso on geographical and magnetic exploration among ice-floes, Liddon Gulf, Melville Island.

were rare and of poor growth, though probably better represented elsewhere in the region. With the vegetation 'closed' almost everywhere, few plants of primarily arctic affinity were in evidence.

The country appeared almost throughout to be of much the same type, undulating about an altitude of some rooo feet and consisting of sand or more often unassorted gravelly material including occasional boulders. No bedrock was seen, and the hills were rarely more than i 50 feet high. The main vegetation types or habitats distinguished, which between them occupied practically the whole of the land or shallow-water area, were ( $I$ ) dryish, open Spruce forest with lichen-rich, heathy ground-vegetation, (2) luxuriant Spruce forest with tall scrub and mossy ground-vegetation, (3) bogs (and boggy forest) and fresher marshes, (4) treeless scrub, including marshy facies, (5) sandy etc. lakeshore and marginal tangle, (6) sheltered tarns and their marginal zonation, (7) stream beds and banks. Examples of each of these, and some other more localized communities, were investigated from the point of view of habitat conditions, floristic composition, and where appropriate the ecological relationships of the dominants.

The only phytosociologically important tree was White Spruce, which in the dryish open forest 'shaded' only about one-tenth of the area, although the individuals were not often more than 7 yards apart. A well-grown example of one of the larger (but by no means largest) trees investigated was still growing actively at the top and coning abundantly; it was $37 \frac{1}{2}$ feet high and $9 \frac{1}{2}$ inches in trunk diameter a foot above the ground, showing about 250 annual rings. An actively growing, typical small tree in the dryish open forest was 15 feet high and had a trunk diameter of 4 inches a foot above ground level; it showed 120 annual rings. In the more luxuriant forest developed under more favourable conditions the trees shaded up to one-third of the area, occasional individuals reaching a height of 45 feet, having a trunk diameter of 15 inches a foot above the ground but still an age of only about 150 years. In the forest, which in one form or another occupied a preponderance of the land area, the surface was often rendered uneven by tussocks, the soil being damp and silty but not very acid; even towards the end of July it 
was usually frozen to within two feet of the surface, and few roots penetrated below that depth. Much of the remaining land area was covered by scrub dominated most typically by mixed Scrub Birch and Northern Willow (Salix glauca s.l.) about two feet high, the absence of trees being in many tracts apparently due to fire.

The last days of July and first few of August were spent in the vicinity of an unnamed lake around lat. $68^{\circ} 55^{\prime} \mathrm{N}$. and long. $124^{\circ} 55^{\prime} \mathrm{W}$. This was outside the forest limit, which appeared to have receded in this region, leaving a very few outliers of scrubby White Spruce but remains of proper trees in a decayed condition. The main vegetation types of the smoothly undulating country were ( 1 ) open 'barrens' of Arctic Avens (Dryas integrifolia) and numerous mixed herbs etc. which often formed a pleasing array in the alltoo-brief growing season, despite the exposed situation and disturbance of the surface almost everywhere by soil 'polygons', (2) swarded slopes on the hillsides, which were often disturbed by solifluction 'streaks', (3) lichen-rich heath with associated Sedges etc., and (4) Willow-Birch scrub up to 2 feet high supporting a subdominant mossy ground-shrub sward. This last appeared to end the succession in favourable situations, being probably the highest type of vegetation attainable under the prevailing conditions over any major portion of the region, though in some sheltered areas the Willows grew higher and formed a more or less pure association. Excavations were attempted of the polygon, solifluction and other soil features; the substratum proved to be for the most part finely comminuted, somewhat calcareous, and usually basic in reaction. In one case under the centre of a polygon it had thawed to a depth of four feet in early August, whereas under the immediately adjacent intervening tract ground-ice extended to within three feet of the surface. A few miles to the west, the valley of the Horton River was forested and the associated flora included southern species not found on the surrounding plains.

A trek from the forest-barrens ecotone northwards to the coast of Darnley Bay and back enabled me to study local conditions and flora along the route, make observations on Caribou and Barren-ground Grizzly Bears, and determine that the timbered belt marked on the latest maps as following the eastern branch of the Horton River does not exist. Also contrary to the indications of the maps, this eastern branch is a mere minor stream which can be forded with ease, the southern branch being much the more important, with a deep valley and forested slopes extending westward from the junction. Subsequently, brief visits were paid to coastal points west of Parry Peninsula and northwards to Cape Bathurst; at each of these points such collecting etc. as time and conditions allowed was accomplished on the ground. During a flight on August 12 from Canso Lake northwards to Langton Bay and thence in a north-westerly direction to the mouth of Horton River, I exposed to the airstream sterile nutrient Petri plates and vaselined slides prepared at my request under the direction of Dr. S. M. Pady at McGill; these, with others exposed later to the northeast (see below), indicated an unexpected abundance of living Bacteria and fungal spores to be present in the air at an altitude of about 5,000 feet ${ }^{4,5}$. As already pointed out in Arctic (vol. I, p. 6o, 1948), the fungal spores found on sticky slides exposed near the Arctic Ocean coast 
include those of three of the most important pathogens of cereal crops in Canada.

In mid-August, my work with the Geodetic Service being complete, I proceeded via Norman Wells and Yellowknife to Cambridge Bay, Victoria Island, to join the Magnetic Survey outfit which with a Canso aircraft was based there and bent on locating the North Magnetic Pole (cf. Arctic, vol. I, pp. 8 et seq., 1948). The terrain around Cambridge Bay was low and flat or gently undulating, mostly of frost-shattered or finely comminuted limestone material supporting dwarf (very often open) vegetation and a limited flora. Lakes and tarns were numerous. The soil was neutral to slightly basic wherever tested. The flora was collected as far as time allowed, and the following main habitats or vegetation-types were distinguished and investigated: Dryas-Salix polygons characteristic of the low domed ridges, Dryas-Carex mat of sheltered depressions, damper grassy-sedgy areas, marshes, erratic boulders and 'birdstones', lake-marginal zones, freshwater, seashore. The largest plants encountered were occasional domed bushes of Richardson's Willow (Salix richardsoni), which were limited by the winter snow-covering but nevertheless reached a maximum height of a foot and a half and in a few instances exceeded I 2 feet in diameter.

From Cambridge Bay several flights were made over the little-known territory to the north and northeast, with a memorable landing in the interior of Prince of Wales Island in the vicinity of the Magnetic Pole (cf. Arctic, vol. I, p. 8, 1948). Here the country was undulating and the flora very limited, with vegetative development so poor that the communities were rarely closed. Indeed apart from the occasional fox's earths which supported a grassy sward, much the most luxuriant and only extensive closed vegetation encountered was on the more sheltered, low-lying plains beside lakes. Here the surface tended to be tussocky and a mixture of grasses, Sedges, mosses, flowering herbs and Arctic Willow (Salix arctica) predominated, though conditions were evidently unfavourable as nothing approaching bushy growth was seen. Even about tarns the marginal vegetation was poor and aquatic moss and algal development limited. The soils wherever tested were neutral to slightly basic in reaction, there being practically no humus deposition; indeed the whole aspect was more reminiscent of such high-arctic lands as northern Spitsbergen or Ellesmere than of such adjacent parts of the Arctic Archipelago as I have visited. However, as far as could be seen from the air in indifferent weather, many other parts of Prince of Wales Island were better vegetated than that of our landing in lat. $73^{\circ} 41^{\prime} \mathrm{N}$. and long. $98^{\circ} 26^{\prime} \mathrm{W}$., where the flora was so meagre that it is thought the vast majority of species of vascular plants were collected in the few hours available for this purpose.

During other flights out of Cambridge Bay, sterile Petri plates and vaselined slides were exposed at an altitude of about 5,00o feet northwards to Somerset Island and southwards to Yellowknife and, ultimately', Edmontonso completing a transect extending over.nearly 20 degrees of latitude and 1500 statute miles ${ }^{4,5}$. Finally, before returning home early in September, brief visits were paid to the forest-barrens ecotone at Point Lake (about $65^{\circ} 20^{\prime} \mathrm{N}$. and $113^{\circ} 40^{\prime}$ W.) and Jolly Lake (about $64^{\circ} \circ 7^{\prime}$ N. and $I 11^{\circ} 55^{\prime}$ W.), at both of 
which places collections of vascular plants were made and the tree outliers (mainly of White Spruce) were observed and sampled for Dr. I. Hustich of Helsinki, Finland. Another current investigation is of the crop contents of Rock Ptarmigan (Lagopus rupestris), which in 1946 gave interesting results in the East ${ }^{6}$. From the 1947 work were brought back between 3,000 and 4,000 collection numbers of vascular plants, and in addition many cryptogams which have been sent to appropriate specialists for determination.

\section{Arctic Flights in 1948}

In 1948 , after spending much of the early part of the summer working in British and Scandinavian herbaria, I proceeded to Fairbanks, Alaska, in August as my plans materialized for a first flight to collect aerobiological material (such as fungal spores, Bacteria, and pollen grains) up to the highest latitudes, including various altitudes in the immediate vicinity of the North Pole. This was accomplished on Sepember 13 when, using a new method devised largely by my McGill colleagues Drs. S. M. Pady and C. D. Kelly and a special apparatus designed in Washington, D.C., in collaboration with U.S. Government specialists but constructed at McGill, I was able periodically to expose sterile Petri plates in front of a $\mathbf{B}_{29}$ 'Superfortress' during most of the special flight of nearly 4,00o miles to, about, and from the North Pole which the U.S.A.F. were generous enough to make for the purpose, and which enabled me also to take samples down to 3,000 feet and up to 25,000 feet over the Pole itself. The results, which it is planned to collate with data on the origin of the air-masses in which the exposures were made, will take some months to work out in detail. Meanwhile it is hoped to make further polar flights in 1949 under full winter and summer conditions, preferably with two or three of us employing different methods of collection contemporaneously.* In this and other ways we hope to benefit by the recently voted support of the Canadian Government and extend the work actively into the future.

While in Alaska I was able to do some collecting at Barter Island, Umiat, and Fairbanks-particularly in support of Prof. Eric Hultén's monumental "Flora of Alaska and Yukon", which is now nearing completion. Point Barrow when I arrived there after the polar flight was already covered with snow and had a prevailing temperature in the vicinity of $-9^{\circ} \mathrm{C}$., so I could do little floristic work although the visit to Dr. Irving and his colleagues of the U.S. Office of Naval Research Arctic Research Laboratory was as stimulating as it was enjoyable. The suspicion, however, that much botanical exploration even of a primary floristic nature still remains to be done, and not only in the less-known areas, was heightened by the fact that, both at Barter Island and Point Barrow, one of the first plants which I encountered on the shore was Carex ursina-new to the flora of Alaska and Yukon.

\footnotetext{
"Since the above was written, Drs. S. M. Pady and C. D. Kelly have been engaged in perfecting two quantitative methods of 'catching', and have made three flights from Montreal to Whitehorse, Yukon Territory, in this connection. Last month (March 1949) the three of us together made a successful flight over the North Pole under winter conditions, employing all our three apparatuses almost continuously while airborne. The results may take many months to work out, but we would like at this stage to acknowledge with deep gratitude our indebtedness to the appropriate authorities in Ottawa, Washington, and Ladd A.F. Base for their parts in making available to us the almost unique facilities without which these researches could not be prosecuted. (Postscript of 9 April 1949-N. P.)
} 


\section{References}

1. Polunin, Nicholas, "Arctic Unfolding: experiences and observations during a Canadian airborne expedition in Northern Ungava, the Nortbwest Territories, and the Arctic Arcbipelago"; London: Hutchinson \& Co., pp. 316 + index (in the press).

2. "Botany of the Canadian Eastern Arctic, Part I Pteridophyta and Spermatophyta"; Canada: Department of Mines and Resources, National Museum Bulletin No. 92, pp. vi + 408, 1940.

ibid. "Part II Thallophyta and Bryophyta" (in collaboration); ibid. No. 97, pp. $\mathrm{v}+573,1947$.

ibid. "Part III Vegetation and Ecology"; ibid. No. 104, pp. vii + 304, 1948.

3. "Additions to the Floras of Southampton and Mansel Islands, Hudson Bay";Contributions from the Gray Herbarium of Harvard University, No. CLXV, pp. 94-105, 1947.

4. $\quad$ S. M. Pady, and C. D. Kelly, "Arctic Aerobiology"; Nature, vol. 160, pp. 876-877, 1947. See also "Aerobiological Investigations in the Arctic and Subarctic"; Arctic, vol. I, pp. 60-61, 1948.

5. Pady, S. M., Kelly, C. D., and Polunin, N., "Arctic Aerobiology, II Preliminary Report on Fungi and Bacteria isolated from the air in 1947"; Nature, vol. 162, pp. 379-381, 1948.

6. Polunin, Nicholas, "Crop-Contents of some Ungava Ptarmigan"; appendix 8, pp. 302307 in "Arctic Unfolding" (1).

\section{ASSOCIATES OF THE ARCTIC INSTITUTE}

During the formative years of the Arctic Institute many friends expressed the hope that a means of close association with its objectives might be made possible. In response to this expression the Institute has developed a membership program for Associates of the Arctic Institute. Associates will receive the journal of the Institute triennially and other reports from time to time. The chief qualification for Associate Membership is interest in Arctic work, and the Board of Governors will welcome the widest possible participation. Dues are $\$ 3.00$ annually and may be paid in United States or Canadian funds and forwarded to either the New York or Montreal offices of the Institute. 